\title{
ピアスによる巨大な耳垂ケロイド例
}

\author{
入江 和美・飯野ゆき子・水谷 俊美
}

宮澤 哲夫・寺島 邦男

\section{A Case of Earlobe Keloid by Ear Piercing}

\author{
Kazumi Irie, Yukiko Iino, Toshimi Mizutani, \\ Tetsuo Miyazawa and Ikuo Terashima \\ (Teikyo University)
}

\begin{abstract}
It is known that ear piercing can cause various complications such as infection, allergic contact dermatitis, granulation, dermoid cyst formation buried earring and so on. We describe a case of earlobe keloid caused by ear piercing. The patient, an 18-year-old female, visited our hospital complaining of a large tumor hanging from the left earlobe. The tumor was excised and a histological examination revealed keloid tissue with subcutaneous clusters of lymphocytes.

An immunohistochemical study of the keloid tissue was performed using a polyclonal antibody against human IgG and IgE. Numerous IgE positive cells, presumably mast cells, were found below the epidermis, suggesting that the keloid was still active and still sensitized by some stimulation. The inflammatory response seemed to have contributed to formation of the large keloid.
\end{abstract}

Key words : earlobe, keloid, ear piercing, mast cell

\section{はじめに}

ピアス装着により，種々のトラブルが生じることが知 られている. その合併症としては, 装着直後の感染をは じめ, 金属アレルギーによる接触性皮膚炎, イアリング の埋没, 肉芽腫や皮様囊胞, さらにケロイド等の腫瘤形 成等が報告されている1)。今回私どもは，ピアス装着後 に生じたケロイドによる巨大な耳垂腫瘤症例を経験した. 本邦ではピアスによる耳垂ケロイドの報告は少なく，著 者らが検索しえた限りでは 4 例2 25) を数えるのみであり， すべて形成外科・皮膚科領域からの報告である. 近年本 邦に括けるピアスの装着はその低年齢化とともに年々増 える傾向にあり, 今後このような症例が耳鼻咽喉科を訪 れる機会があることが予想される. そこで, この症例に 関しその詳細を報告するとともに, 腫瘤を免疫病理組織 学的にも調べ，その形成機序につき検討を加えた.

\section{症例}

症例 : 18歳, 女性.

主訴：左耳垂腫瘤.

既往症, 家族歴 : 特記すべさ事なし.

現病歴: 平成 5 年 8 月, 16 歳時, 左耳垂に 2 力所, 右 耳垂に 1 カ所のピアス小孔を開けた。 その後特に異常な く両耳にピアスを装着していたが，3 カ月前より左耳垂 腫脹，発赤が出現した. その後たびたび衣服の着脱時に 左耳垂に衣服が触れ，出血をくりかえすようになった. 徐々に左耳垂に腫瘤を形成し増大してさたため, 平成 6 年 3 月 11 日に当科を受診した.

初診時所見 : 左耳垂にはピアス小孔が 2 カ所開けられ て持り，下方のピアス孔より耳垂の一部が球状に下垂し， 表面平滑な大きさ $3.0 \times 3.1 \mathrm{~cm}$ の腫瘤を形成していた (図 1 ). 腫瘤の上半部には軽度の発赤が認められた。右 


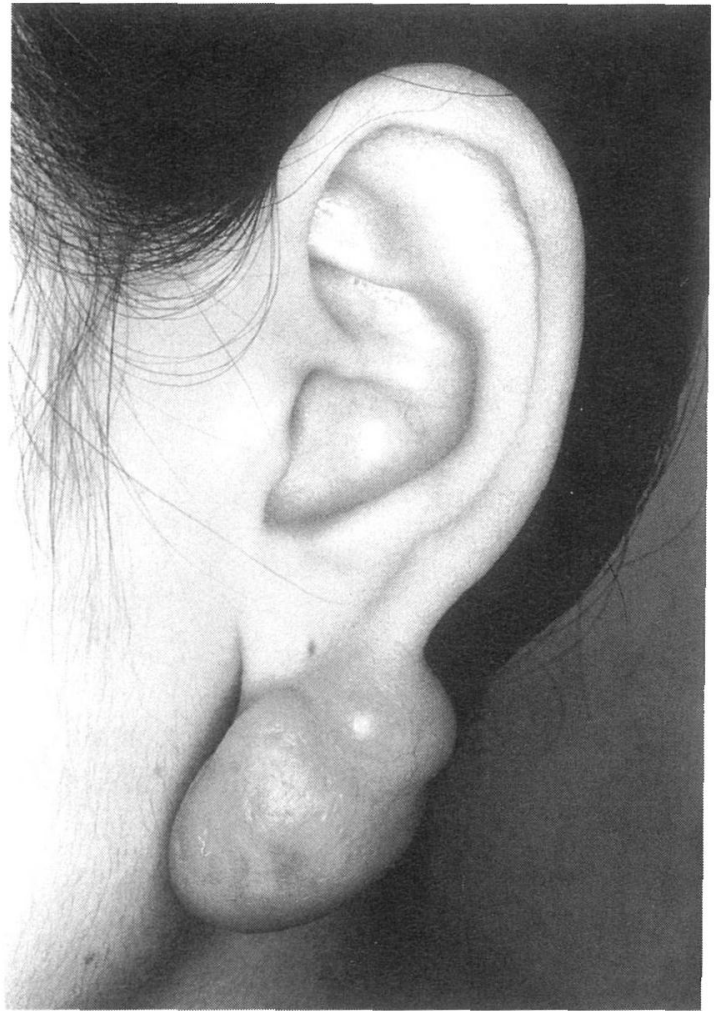

図 1 左耳介局所所見
耳垂には 1 カ所の小孔が認められたが，周囲の皮膚には 発赤や硬結などの異常は認められなかった。そのほか鼓 膜，鼻咽喉頭には異常所見は認められなかった。またア トピー等, 明確なアレルギー性素因は認められなかった。 以上の現病歴特よび局所所見から，ピアスによる表皮囊 胞，むるいは廄痕性腫瘤を疑い MRI 撮影をした。

頭部 MRI 所見（図 2)：左耳垂から垂れ下がるように 内部が T1 強調像では低信号, T2 強調像ではさらに低 信号の腫瘤が認められる。この信号強度から T2 強調像 で高信号を呈する表皮囊胞は否定的で，血流がそしい線 維性の腫瘤が考光られた。

手術所見: 平成 6 年 4 月 13 日, 局所麻酔下飞左耳垂腫 瘤摘出術を施行した。腫瘤は被膜や囊胞壁には覆われて おらず，健常耳垂部の境界は明瞭ではなかったため，瘢 痕状に硬い部分のみ耳喠の形を保存するように腫瘤表面 の皮膚とともに摘出した。摘出標本の割面では，腫瘤は 皮膚に覆われ中心部は全て硬い結合織様で，耳垂付着部 にのみ一部脂肪織が認められた。

病理組織所見：細胞間の境界ははっきりしておらず, 線維芽細胞が増生し，膠原線維が索状に様々な方向に走 行していた。表層には円形細胞浸潤を伴う血管増殖が観

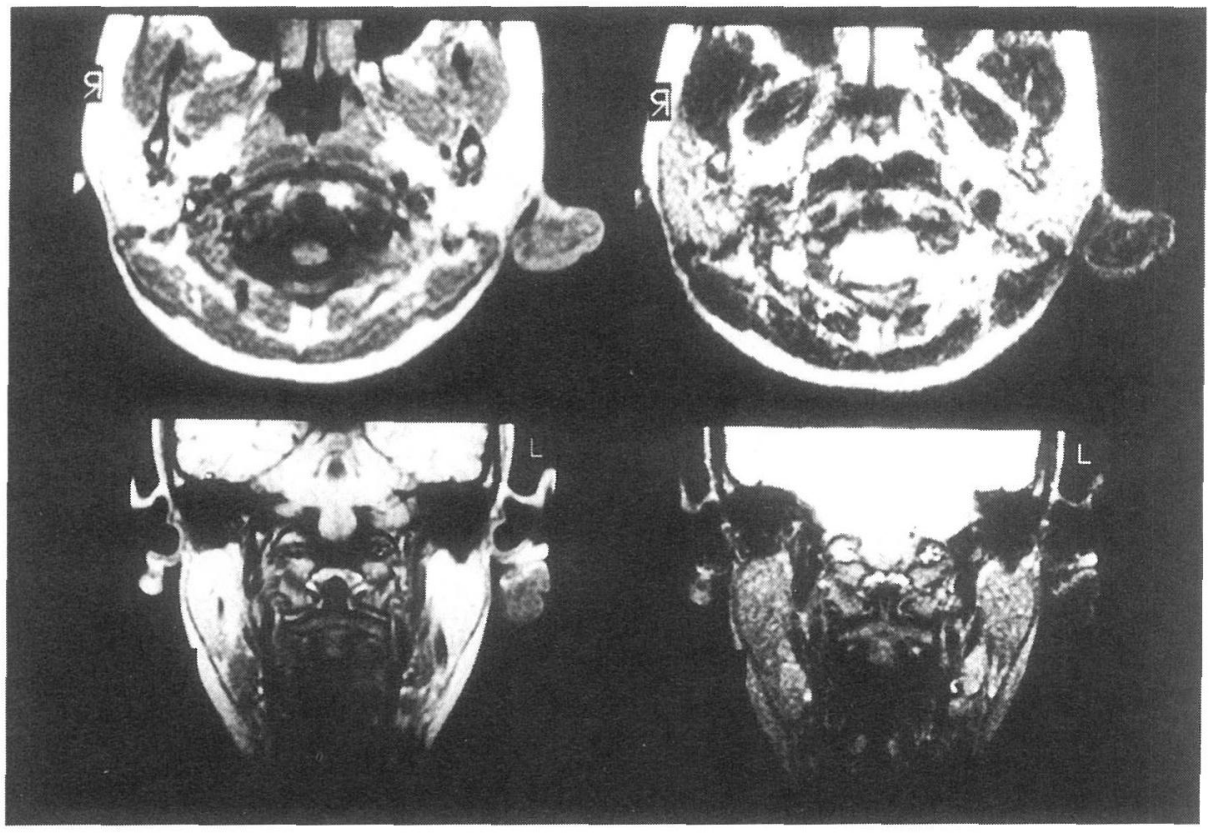

図 2 MRI 画像

上段 : 水平断, 下段 : 冠状断

いずれも左が $\mathrm{T} 1$ 強調像，右が $\mathrm{T} 2$ 強調像 
察された。また耳垂付着部付近の深層の一部には、リン 俅の集積が認められ肧中心様構造を伴っていた(図 3).以上の組織所見から，瘵痕性ケロイドと䛦断した。 また IgG，IgE に対するポリクローナル抗体を用い LSAB 法にて免疫染色を施した。 IgG 陽性細胞はりン 只球が集積している胚中心の辺縁にのみ，わずかと観察 された。一方 IgE 陽性細胞は, 肧中心の辺縁, 拈よび 皮下組織浅層に多数観察された(図 4)。この IgE 陽性 細胞は細胞の形態から肥満細胞と考光られた。

経過: 術後は特に問題なく創の治癒も良好で抜系後退 院となった。術後 1 年 8 カ月経過した現在でる腫瘤の再 発は認められていない。

\section{考察}

1）ピアスによる合併症について

ピアスによる合併症の頻度は比較的高く, 欧米ではピ
アス装用者の $1 / 3$ から $1 / 2$ Kなんらかのトラブルが見ら

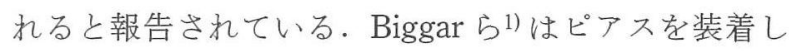
ている497名の女性にアンケート調査した結果, なんら かの合併症を有するものが $34 \%$ に認められたと報告して いる。合併症は，友人同士で小孔を開けた場合で $36 \%$, 医療従事者が施行した場合 $31 \%$ ，デパートの店員で $28 \%$ に見られている。また装着方法では針を用いた場合 $33 \%$ ， ピアス孔作成器具を用いた場合 $29 \%$ ，とがった鋲を用い た場合 $22 \%$ で合併症が出現している。すなわち，合併症 の出現率と,どのような施設で誰がピアスの小孔を開け たか，さらに装着方法による有意な相関は認められてい ない、すなわちピアスによるトラブルはピアス装着時の 要因より, その後のケアや本人の体質によるものが原因 である可能性が強いと述べている.

合併症として, Hendricks ${ }^{6}$ ( は局所の炎症, 肉芽腫形 成, 撚痕・ケロイド形成, 浮腫・血腫, リンパ組織の過

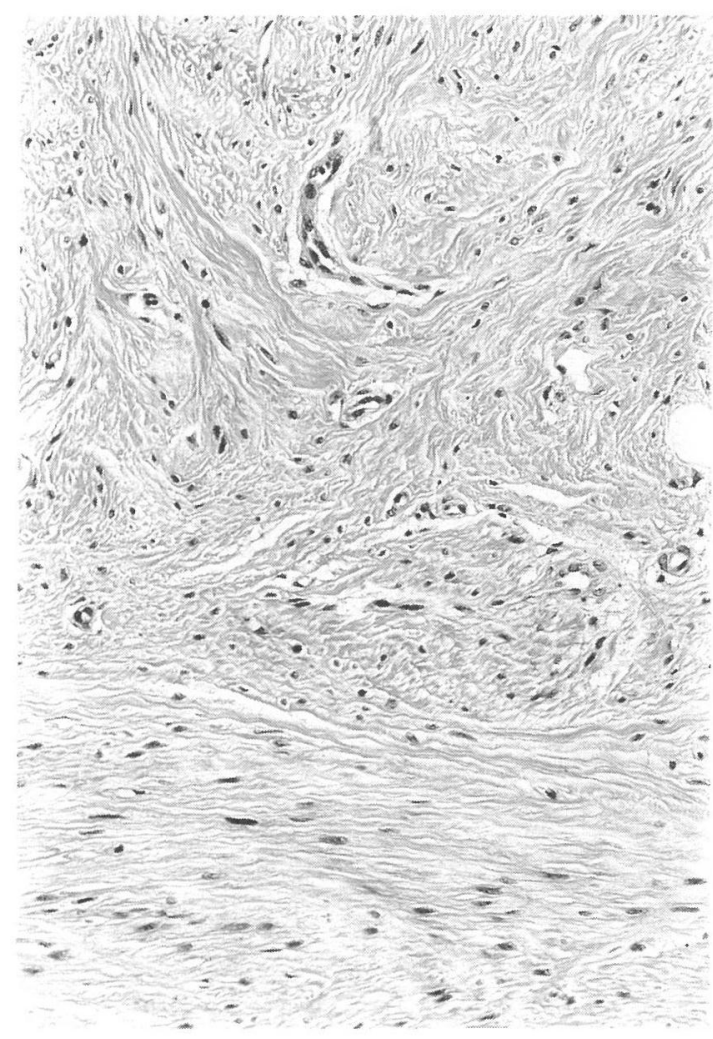

( a )

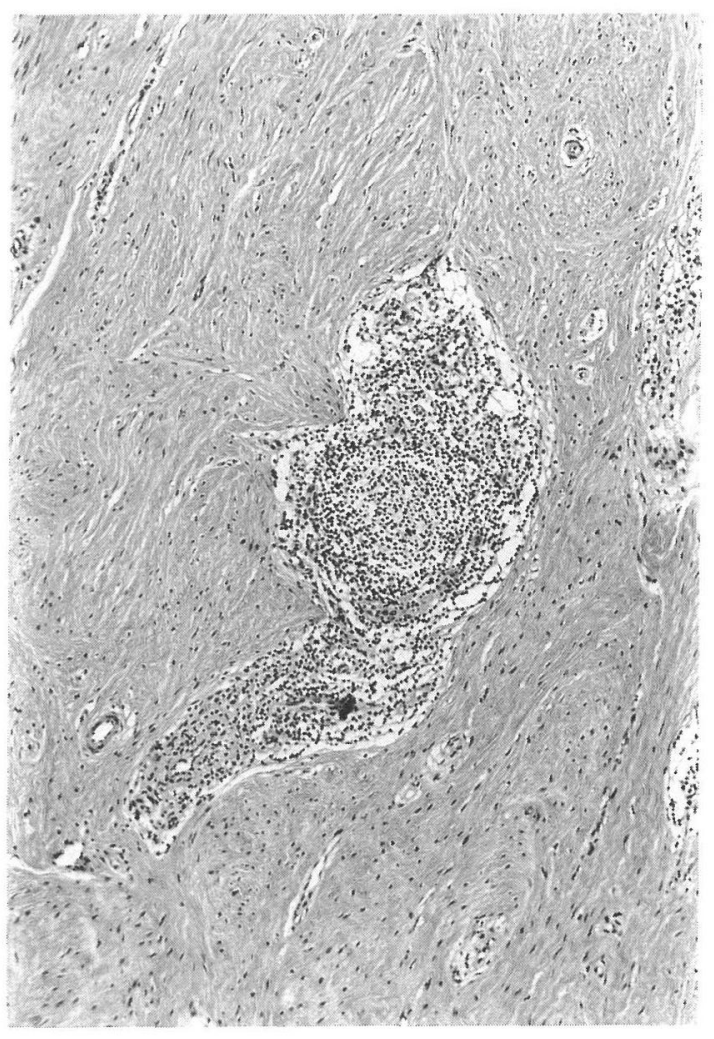

(b)

図 3 病理組織像 (HE 染色)

a : 線維芽細胞を伴った膠原線維が索状に走行している $(\times 200)$.

b : 茎部付近では胚中心構造を伴うリンパ球の集積が認められる $(\times 100)$. 


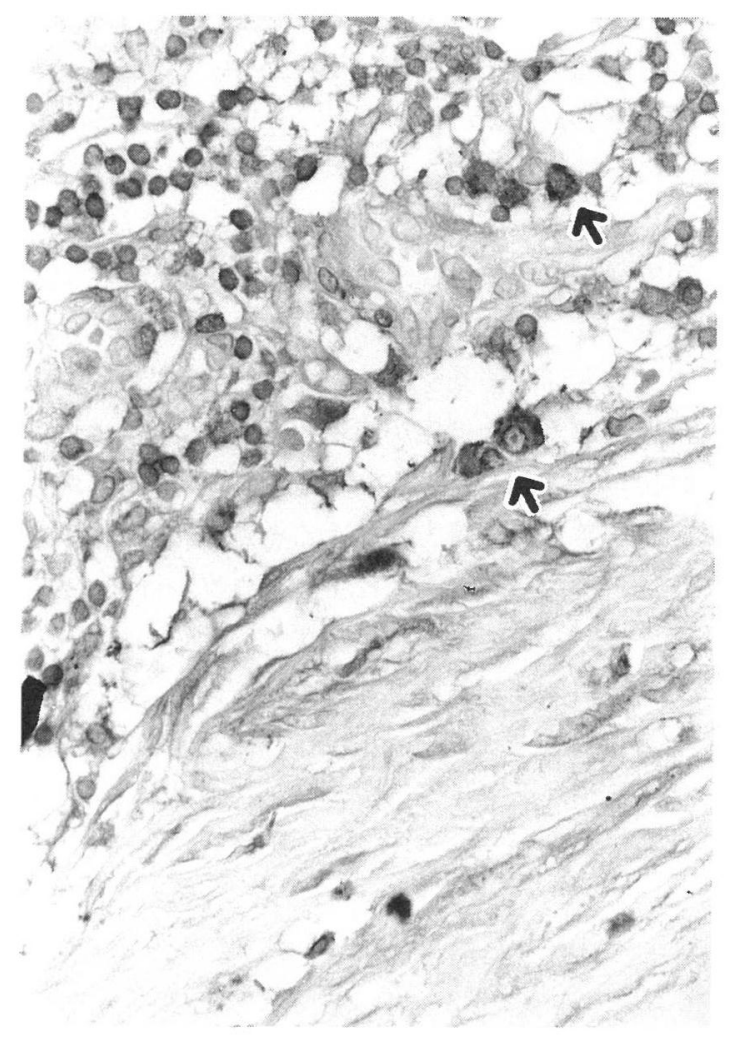

(a)

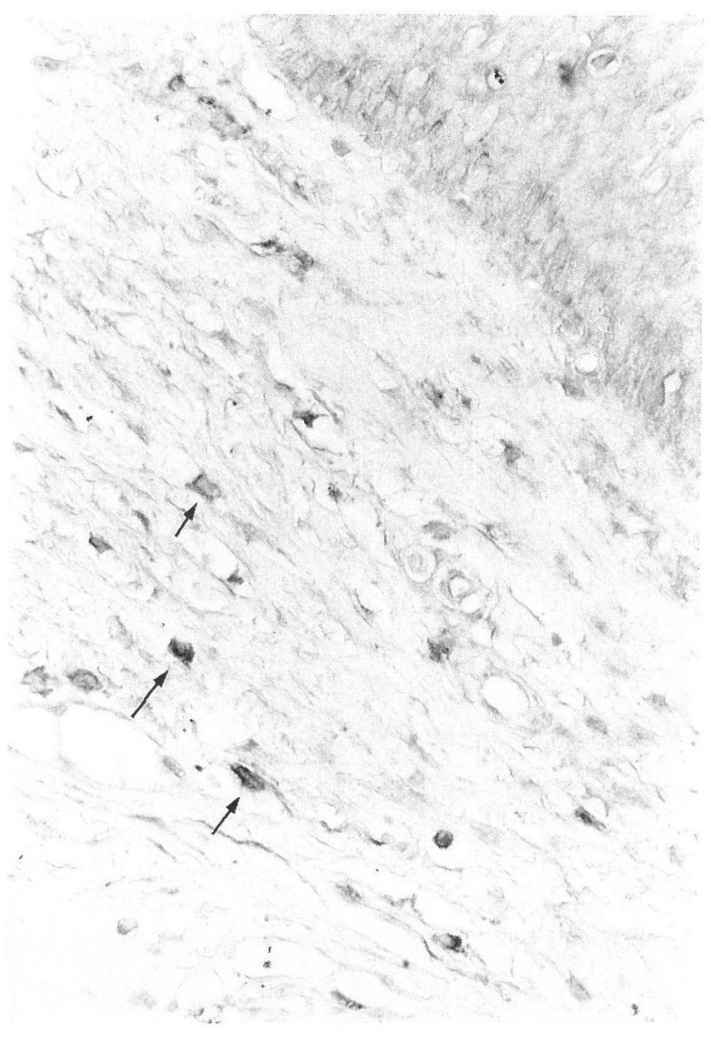

( b )

図 4 免疫病理組織像

a (IgG 染色)：リンパ球の集積部位に IgG 陽性細胞(矢印)が認められる $(\times 400)$.

b (IgE 染色) : 皮下組織に多数の $\operatorname{IgE}$ 陽性細胞(矢印)が観察される $(\times 400)$.

形成，アレルギー性接触性皮膚炎，囊腫形成等があると 述べている. Cortese ら〕は73名のピアスを装着した看 護学生を検討し，52\%になんらかのトラブルを見出し， その頻度として，アレルギー性接触性皮膚炎 $19 \%$ ，局所 の炎症 $15 \%$, 出血15\%, 化膿性出出液 $15 \%$, 非化膿性參 出液または痂皮形成 $12 \%$, 囊腫形成 $3 \%$, 耳垂裂傷 $1 \%$ と報告している。やはり多いものは化膿性あるいはアレ ルギー性の炎症であるが，本症例の様に，比較的短期間 でピアス装着後に耳垂に巨大腫瘤を生じた報告は稀であ る。本邦での本症例を含めた 5 例の中では，松崎ら22の 報告した $2.7 \times 4.5 \mathrm{~cm}$ の腫瘤についで 2 番目に大きな 腫瘤であった。

\section{2) ピアスに上るケロイドの形成機序}

ピアス装着後にケロイドが生じる頻度関しては, Biggar ら ${ }^{1)}$ の報告に上れば合併症中 $3 \%$ の出現率であ り, 決して高いものではない。しかし，耳垂部は以前か
らケロイドの好発部位として知られている。Cosman ら ${ }^{8)}$ は種々の部位のケロイドを外科的に切除した患者 448名中, 耳垂部のケロイドは140名 (32\%)を占めたとし ている，その原因として，48名（33\%)はピアスによる両 側性の耳垂ケロイド症例であった。この結果からみると， 全ケロイド症例に特けるピアスによる耳垂ケロイドの占 める割合は約 $10 \%$ となり，決して少ないものではないよ らである。これらのピアスによる耳垂ケロイド症例は， 10〜30歳の女性に多く, 人種的には黒人やアジア人に生 じやすいと報告されている6)，本症例は18歳の女性であ るが，本邦で報告されている 4 症例る22歳〜34歳のいず れも女性である。これは女性でこの年代が最もピアスの 装着頻度が高いからであるう。

ケロイド形成, 増殖の因子の 1 つとして, 張力や刺激 が指摘されている。梪垂部は重力のかかりやすい部位で ありまたピアスや毛髪に上る刺激が加わりやすいこと 
がケロイドを生じやすくしている可能性がある. 今回の 症例では，ピアスによる刺激のため炎症をくりかえし， それが瘵痕化したところにさらに衣服の着脱の際に頻繁 に接触しさらに刺激が加わったものと思われる.いった 儿腫瘤を形成すると，その重みによる張力で，ますます ケロイドを増大させることになり，巨大な腫瘤形成にい たったと考えられる。

本症例は臨床的に表皮囊胞も考兵たが, MRI 画像に て瘢痕性腫瘤を疑い, 病理組織診断で, ケロイドと確定 診断された。この組織像は線維芽細胞を伴って膠原線維 が不規則に増殖しており，典型的なケロイドの像であっ た。しかし，上皮下の一部にリンパ球の集積をみたこと から，なんらかの炎症が関与している可能性を考兄, 免 疫組織学的にも検討した. その結果, IgG 陽性細胞はご くわずか認められるのみであったが, 肥満細胞と思われ る IgE 陽性細胞は皮下組織の浅層に多数観察された.

皮膚組織には部位により異なるものの通常肥満細胞が 観察される. しかし瘢痕ケロイドの活動期にはその数の 増加を認める9 . 一方後述するステロイドの局注や压迫 治療後のケロイド中の肥満細胞は減少を認めるとの報告 がある ${ }^{9110)}$. 肥満細胞の役割に関しては, 免疫反応や物 理的, 化学的刺激により肥満細胞から脱顆粒により放出 されるヒスタミン等のケミカルメディエーターが，かゆ みや血管の拡張，さらには結合織の代謝に深く関与して いると考えられている11)。本症例においては，IgE 陽性 の肥満細胞が数多く観察されたことから，かなり活動性 のケロイドであり，さらに IgG 陽性細胞を伴うリンパ 球の集積も観察されたことから，なんらかの刺激にて感 作されている状態であったことが推測される。このよう な慢性の刺激により，ケミカルメディエーターの放出が 生じ，短期間で巨大な腫瘤に成長した可能性がある.

3 ) 耳垂ケロイドの治療と予後

耳垂のケロイドに対する治療は他の部位における康痕 性ケロイドと同様, 保存療法と手術療法に分けられる. 保存療法としては, 副腎皮質ホルモンの局注 ${ }^{12)}$, ボタン やスプリントによる持続的な圧迫13144) 等が試みられて いる．また手術療法は，手術そのものがケロイドを生じ る誘因となりらるため, 論議がある。しかしある程度大 きいケロイドは保存療法で治癒させるのは無理であるた め, 手術療法に加兄, 術前あるいは術後に副腎皮質ホル モンの局注や放射線照射を組み合わせる方法1516) も取 られている。
ピアスによるケロイドの再発は比較的多く, Cosman ら 8 によれば手術的に除去した $22 \%$ に再発を認めたと報 告している．さらに術前のケロイドのサイズが大きい注 ど，また発生してから手術までの期間が短いほど再発し やすいと述べている．また術後に放射線治療を行ならこ とにより，再発頻度が減少するとも報告している．今回 の症例では巨大なケロイドであったため，はじめから手 術療法を選択した．術後特に追加治療は行なっていない が， 1 年 8 カ月経過した現在も再発は認められていない。 しかし，サイズが大きいこと，短期間で巨大な腫瘤にな ったことを考えると，今後十分に経過を観察する必要が あると考觉る。

\section{まとめ}

ピアス装着後に生じた巨大な耳垂腫瘤症例を報告した。 病理組織学的にはケロイドであった. 免疫組織学的検索 により，かなり活動性のケロイドであり，慢性の刺激に よる感作状態にあることが推察され，これが巨大化した 要因と考えられた.

本論文の要旨は日本耳鼻咽喉科学会東京都地方部会第106回 学術講演会にてロ演した.

\section{参考文献}

1) Biggar RJ and Haughie GE : Medical problems of ear piercing. NY State J Med $75: 1460 \sim 1462,1975$.

2 ）松崎美千代, 丸山友裕, 山口茂光, 他 : ピアス孔ょり生じ た巨大なケロイド。形成外科 $30: 392,1987$.

3 ）林 正幸, 杉山朝美, 中島 弘: 金製ピアス型イアリング によるケロイド。日皮会誌 $97: 1059,1987$.

4 ) 利根川均, 平井 隆, 梅田敏彦, 他: ピアス型イアリング 装着後にみられた耳垂部ケロイドの治療経験. 日美外報 $12: 102 \sim 106,1990$.

5 ) 中村元信, 内沼栄樹, 伊藤正嗣, 他 : ピアス後に発生した ケロイドの 1 症例. 日美外報 $15: 146 \sim 152,1993$.

6 ) Hendricks WM : Complications of ear piercing; treatment and prevention. Cutis $48:$ 386 394, 1991.

7 ) Cortese TA and Dickey RA : Complications of ear piercing. AFP $4: 66 \sim 72,1971$.

8 ) Cosman B and Wolff M : Bilateral earlobe keloids. Plast Reconstr Surg 53 : 540 544, 1974.

9 ) Kischer CW, Bunce H and Shetlar MR : Mast cell analyses in hypertrophic scars, hypertrophic scars treated with pressure and mature scars. J Invest Dermatol $70: 355 \sim$ 357, 1978. 
10）森口隆彦, 井上邦雄, 小川 豊 : 肥厚性㾝痕組織に打ける 肥満細胞の動向について. 日形会誌 $1: 19 \sim 28,1981$.

11）森口隆彦：創傷治癒における肥満細胞およびュラーゲン架 橋の変化. 形成外科 $26: 286 \sim 294,1983$.

12) Moustafa MFH and Abdel-Fattah AMA : Keloids of the ear lobes in Egypt ; their rarity in childhood and their treatment. Br J Plast Surg $29:$ 59 60, 1976.

13) Brent $B:$ The role of pressure therapy in management of earlobe keloids ; preliminary report of a controlled study. Ann Plast Surg $1: 579 \sim 581,1978$.

14) Mercer DM and Studd DMM : "Oyster splints" ; a new compression device for the treatment of keloid scars of the ear. Br J Plast Surg $36:$ 75 78, 1983.

15) Weimar VM and Ceilley RI : Surgical gems, treatment of keloids on ear lobes. J Dermatol Surg Oncol 5 : 522 523, 1979.

16) Howell $S$, Warpeha R and Brent $B$ : A technique for excising earlobe keloids. Surg Gynecol Obstet 141 : 438, 1975.

$$
\left.\begin{array}{l}
\text { 原稿受付 : 平成 } 8 \text { 年 } 2 \text { 月 } 2 \text { 日 } \\
\text { 原稿採択 : 平成 } 8 \text { 年 } 3 \text { 月 } 13 \text { 日 } \\
\text { 別刷請求先 : 入江和美 } \\
\text { 干1 } 123 \text { 東京都足立区西新井本町 } 5-7-14 \quad . \\
\text { 医療法人社団成和会西新井病院耳鼻咽喉科 }
\end{array}\right)
$$

